\title{
エレクトロンチャンネリングパターンによる
} 結晶方位自動解析システムの開発

$$
\text { 船木秀一 } * \text {. 谷野 満 } * 2 \cdot \text { 小林俊文 } * 3 \cdot \text { 南郷脩史 } * 3
$$

\section{Development of the System for Automatic Crystallographic Orientation Analysis by Electron Channelling Pattern}

\section{Shuichi Funaki, Mitsuru Tanino, Toshifumi Kobayashi and Nobuhito NangoH}

\begin{abstract}
Synopsis :
Electron Channelling Pattern (ECP) is useful for determination of the precise orientation of individual grain observed under a scanning electron microscope. It is necessary to analyse a large number of crystals to obtain crystallographic information which is useful to understand and control the properties of various materials.

However, previously reported ECP methods required a laborious work and/or expertness.

In order to save time and labor, in this study, ECPs are recorded to hard disks linked to the personal computer, followed by orientation analysis by image-processing (image enhancement, Hough transformation, detection of lines, etc.), which leads to automatic determination of the crystallographic orientation.

The functions of the present system are summarized as follows ;

(1) The achievement rate of automatic drawing-and-analysis in the routine work is more than $95 \%$ (about 2300 grains analysed).

(2) 240 images are handled over one night $(16 \mathrm{~h})$ with no operator $(4 \mathrm{~min} /$ image $)$.

(3) ECP images, which are hard to analyse automatically due to broadness, can be easily treated by manual method (1 min/image).

The development of this system has achieved decrease in labor. Furthermore, even unpracticed person can easily operate it.

In the future, completely automatic ECP analysis without any operator will become possible by attaching an automatic specimen-displacing stage to the ECP/SEM.

Key words : electron channelling pattern; scanning electron microscope; crystallographic orientation analysis ; personal computer ; image processing ; automation.
\end{abstract}

\section{1. 緒}

\section{言}

電磁鋼の磁気特性，あるいは薄板およびステンレス鋼 板の加工性が結晶粒方位分布に大きく支配されることは よく知られており，特性の良い材料を製造するためには 目的に応じて結晶方位分布を適正に制御する必要があ る. 方位分布を的確に制御するためには，従来から広く 利用されている X 線極点図のようなマクロな方位情報 だけでなく，個々の結晶粒に関するミクロな方位情報も 必要とされる. そのようなミクロな結晶方位分布情報と 材料特性の関係を理解するためには, 多数の結晶粒の方
位を測定することが必要になるが, 従来用いられてきた ファセットピット法, コッセル法, 透過電子顕微鏡法な どは簡便性, 迅速性, 正確さ, 大量処理などの点でいず れも一長一短があり必ずしも満足できる方法ではなかっ た.

これらの方法にたいしてエレクトロンチャンネリング パターン (以下 ECP と略す) 法は SEM にロッキング コイルを取り付け，SEM 観察した場所の ECP を測定, 解析することにより，目的とする結晶粒 $(>3 \mu \mathrm{m})$ の方 位を簡便, かつ正確に決定できるだけでなく, 結晶の完 全性や試料の表面状態に関する情報も定性的に得られる

平成元年 12 月 12 日受付 (Received Dec. 12, 1989)

* 新日本製鉄(株)解析科学研究センター (Materials Characterization Research Lab., Nippon Steel Corp., 5-10-1

Fuchinobe Sagamihara 229)

*2 新日本製鉄(株)解析科学研究センター（現：東北大学）工博 (Materials Characterization Research Lab., Nippon Steel Corp., Now Tohoku University)

*3 ラトックシステムエンジニアリング(株) (Ratoc System Engineering Co., Ltd.) 


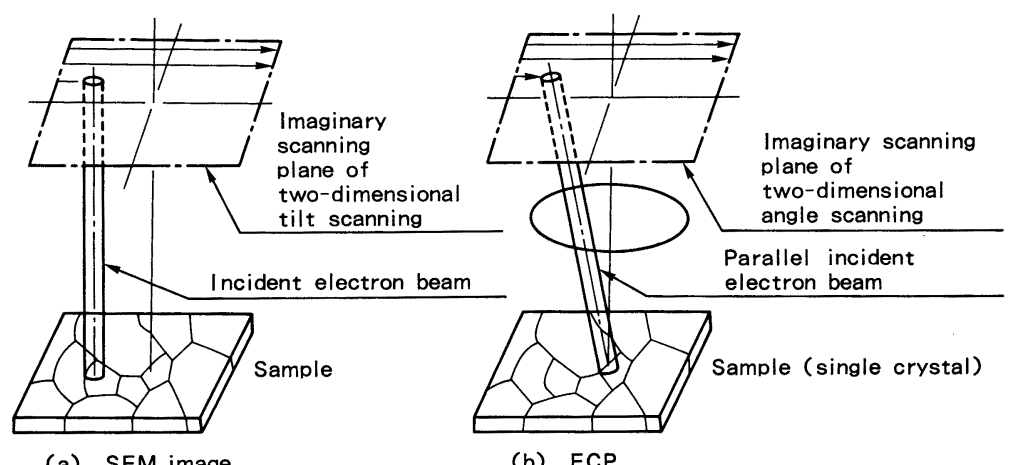

(a) SEM image

(b) ECP

Fig. 1. Comparison of SEM image and ECP in principle of generation.

ことなどの特徴を有し, しかも大量処理が容易な方法で ある.

しかし，ECP から結晶方位を求めることは，一般に (001)，(101)，(111）のような低指数面を除いて簡単で はない。 そこで ECP と菊池線図の方位解析が類似して いることを利用して 1977 年頃より各種の解析方法が開

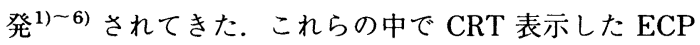
画像をディジタイザーにより線画化し, 計算機で作図し た候補方位群 (数種類) の ECP 線画との比較照合によ りもっともマッチングの良い ECP 線画を解とする解析 方法 ${ }^{6)}$ は精度がよい, 簡便, 経験を要しない点で他法に 比へ優れている．しかし，この方法においてもマニュア ル処理が必須であり多数の結晶粒を対象とする場合, 線 画化に多くの時間と労力を要する問題点があった.

本研究では, パーソナルコンピューター（以下パソコ ンと略す）と画像プロセッサーを活用し，また独自に開 発したソフトウエアーを用いて ECP の自動線画化を行 い, 従来の解析処理方法 ${ }^{6)}$ とドッキングさせた「ECP による結晶方位自動解析システム」の有用性について鉄 （体心立方格子）を対象に検討した。

実際の材料の場合, 結晶粒の大きさ, 歪みあるいは表 面皮膜の存在などにより必ずしも鮮明な ECP が得られ るとは限らない. 従来のディジタイザーによるマニュア ル入力をベースにした解析法の場合, 熟練した測定者で あれば線画化はおおむね正確になされるため，解析の䛊 りはほとんど生じない.しかし計算機による自動線画化 の場合は，つねに正しい線画化が行われるという保証が ないため, 得られた解析結果の妥当性については十分に 吟味することが必要である。それゆえ，ECP 像の自動 線画化にあたっては，方位解析に必要な線情報をもれな く抽出すること，また抽出した線情報の中から解析に必 要な線情報を的確に取捨選択し, 正しく方位解析を実行
させることを目的として，自動解析が可能なシステムを 開発した.

\section{ECP の原理}

Fig. 1 は SEM 像および ECP 像の発生原理をモデル 的に比較したものである. SEM は電子ビームを試料表 面上で 2 次元的に走查し, 試料の凹凸などに対応して発 生した 2 次電子などの輝度変化を CRT 上に表示する. 一方, ECP は電子ビームを試料上の一点に固定し, ビー ムを奥から手前に倒しながら順次走査する（ビームロッ キング）ことにより試料結晶面のブラッグ条件にもとづ

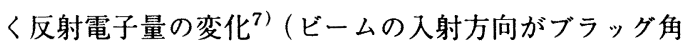
より小さい時は透過能が減少して反射電子が多く放出さ れ，逆に少し大きい時は透過能が増大することにより反

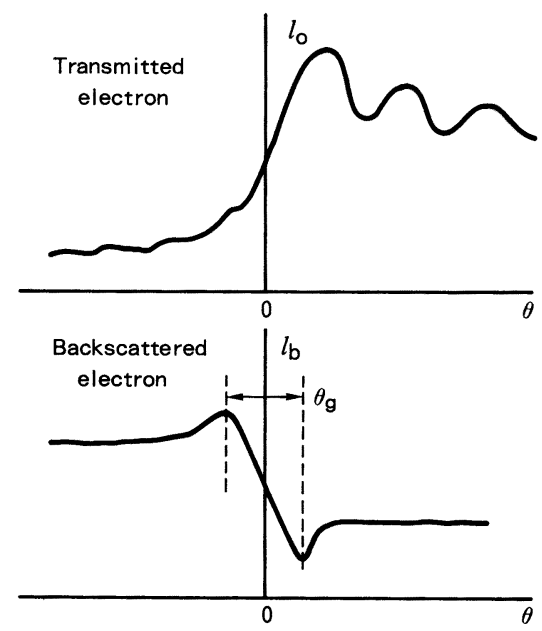

Fig. 2. Dependence of the intensity of transmitted and backscattered electron beam on the incident angle. 
射電子が少なくなるため，ブラッグ条件の近くでコント ラストが急激に変化し線として識別できる) が CRTに 表示される。これらの関係を Fig. $2^{7)}$ に，実際の ECP 像を Photo. 1 に示す. ECP は Coates ${ }^{8)}$ 像あるいは擬 菊池線像とも呼ばれ，常に白黒の線が平行な対（白黒ぺ アー線）をなして現れ，結晶を傾けたとき，あるいは回 転したときには，これらの線はあたかも結晶に固定され ているかのように相対的に位置を移動する。この ECP の形，向きおよび白黒ペアー線の幅は測定対象の結晶構 造, 格子常数, 結晶方位, 測定条件によって変化するが, 同一試料を同一条件で測定したときえられるパターンの 形は結晶方位のみに依存する。

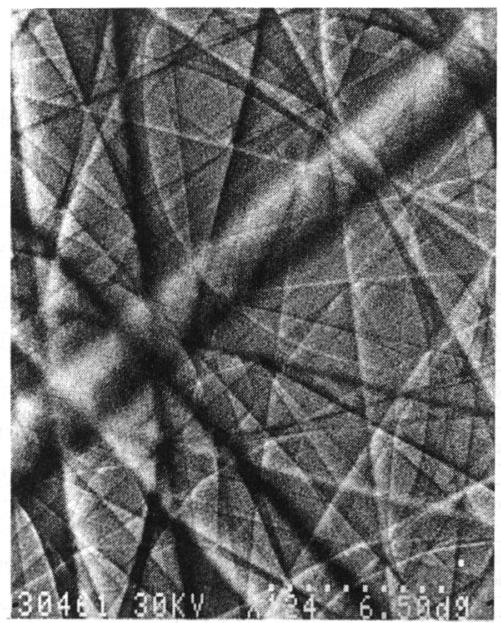

Photo. 1. Typical example of ECP.

\section{ECP の自動線画化, 自動解析処理のプロセス}

\section{$3 \cdot 1$ ECP の解析法について}

ECP を構成する白黑ペアー線の幅は格子面間隔に対 応し，また相互の交叉角は結晶面間角に対応するのでこ れらを計測，解析することによって方位が決定できる。 現在のところ ECP 像を線画化しそれを用いて解析する ことがきわめて簡便で経験を要しない方法 ${ }^{6)}$ である.

本稿で述べる ECP の自動線画, 自動解析よりなる結 晶方位自動解析システムは線画化, 解析に要する時間と 労力を省力化したものである。まず解析方法について述 ベる．本解析法は森らの方法 ${ }^{3)}$ をベースにパソコン対応 に書き換えたことにあり，その過程は(1)CRT 上の ECP 像を用いてディジタイザーにより ECP を構成する線の 両端部を指定するマニュアル処理によって数組の白黒ペ アー線を線画化する（この線画化において最初に入力す る 2 組はできるだけ中心部の近くで大きい角度で交叉し たものを選ぶのが良い) (2最初に入力した 2 組の白黒ペ アー線の幅およびその交叉角を自動的に算出し,この值 をもとに誤差を考慮に入れて数個の候補パターンを計算 機上に発生させる(3)マニュアルによって線画化した線画 パターンと候補パターンを計算機上で最小自乗法により 比較照合し正しい解を求めることである。この方位解析 の過程においては, まず 2 組のペアー線を用いて候補パ ターンを発生させる (板面法線方向を $h k l$ とする). そ の候補パターンは $h k l$ および $h \bar{k} l^{\dagger}$ を必ず含むため, そ

$\dagger h k l$ の属する $\mathrm{T}_{1}$ 領域, $h \bar{k} l$ の属する $\mathrm{T}_{2}$ 領域はステレオ三角形の底面 である(001) と（101）を結ぶ線を軸として鏡面対称の関係にある.

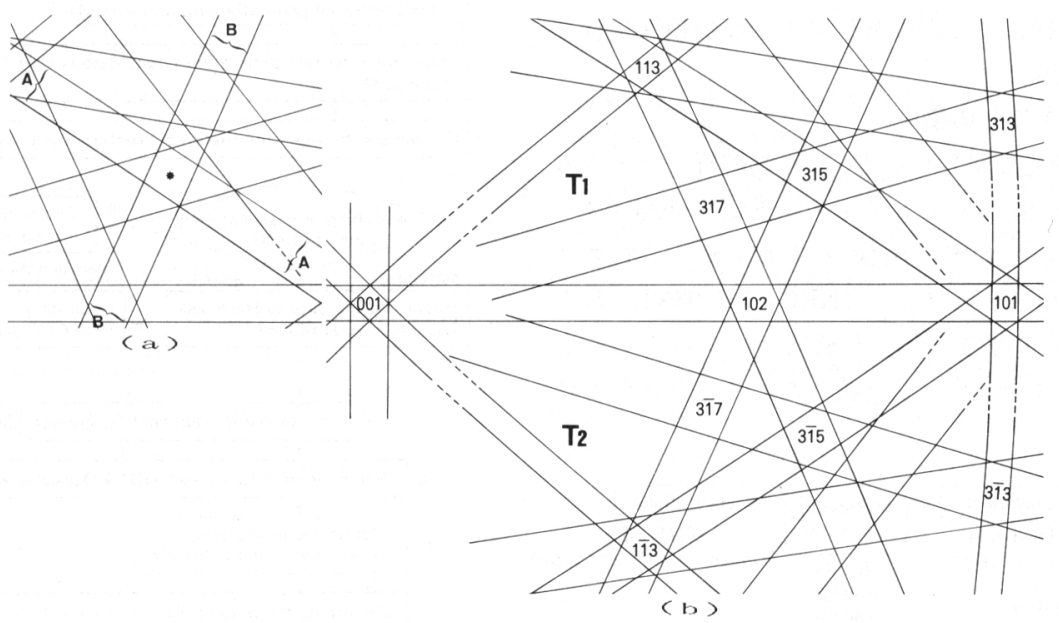

Fig. 3. Drawn line image (a) and the computer generated ECP (b) of nearly (102) oriented $\alpha$-iron (body center cubic). 
のどちらが正しい方位であるか否かは決められないが, 第 3 のあるいは第 4 のペアー線の存在位置を比較するこ とにより正しい方位を一義的に決定することができる. このことを実例で示す. Fig. 3（a) は線画化した ECP, （b）は体心立方格子の（102）近傍における $h k l （ \mathrm{~T}_{1}$ 領 域）および $h \bar{k} l\left(\mathrm{~T}_{2}\right.$ 領域)のモデル ECP 像を示す。こ の方位解析にあたって最初に入力した 2 組のペアー線を A， B (Fig. $3(\mathrm{a}))$ とすればこれより発生する候補パ ターンはペアー線の幅拉よび相互の角度が同じである $\mathrm{T}_{1}$ に属する（315）方位および $\mathrm{T}_{2}$ に属する（315）方位 が他の候補パターンとともに含まれているはずである. 両者は鏡面対称にあり平行, 回転移動によって合致しな いため $\mathrm{T}_{1}, \mathrm{~T}_{2}$ の区別は他のペアー線の存在位置によっ て明確に判定でき,この例の場合, 測定した ECP の方 位は（315）と決定できる。このようにマニュアルによ る線画化は人間が線の存在を判定するため解析にともな う䛊りはほとんど生じないが, 自動的な線画を基盤とし た解析においてはとくに結晶の対称性が良い(111)， (111) 近傍の方位は解析にあたって注意を要する.

なお, 結晶面指数付けの解析結果の表示については $l \geqq h \geqq k$ とし, つねに $h, l$ は正の值を, $k$ は正, 負の 値を，uvw は正負いずれかの值をとるものとした．した がって三角形 $\mathrm{T}_{1}$ 内の結晶方位の表示は $(h k l)[u v w]$, 三角形 $\mathrm{T}_{2}$ 内は $(h \bar{k} l)[u v w]$ となる.

一方，その信頼性については正確な方位がわかってい る 40 種類のモデル ECP をマニュアルにて線画化し (CRT 上の線画化以外に写真を対象とした機能も有す る）自動解析した結果の方位とモデルとの方位差をもっ て評価した。その結果, 方位差の平均は 0.1 度（最大 0.2 度) で計算機による自動解析は十分な信頼性を有し ていることが判明した。

\section{$3 \cdot 2$ ハードウエアーの構成}

Fig. 4 は本研究で開発した ECP 自動解析システムの ハードウエアー構成を示しており, ECP/SEM(メー カーを問わない）本体に画像プロセッサー（ネクサ ス-6510)，16 ビットパソコン（NEC : PC-98XL）扰よ び ECP 画像記録用のカセット磁気テープ付きハード ディスク（40MB を2台）を直結した。このシステムは

\begin{tabular}{|c|c|c|c|}
\hline \multirow{2}{*}{$\begin{array}{c}\text { ECP } \\
\text { (SEM) }\end{array}$} & Image processor & \multirow{2}{*}{$\begin{array}{l}\text { Personal } \\
\text { computer }\end{array}$} & Hard disks \\
\hline & \multirow{2}{*}{$\begin{array}{l}512 \times 480 \text { 8-bits } \\
\text { image processing }\end{array}$} & & \multirow{2}{*}{$\begin{array}{c}40 \mathrm{MB} \times 2 \\
\text { (Cassette magnetic tape) }\end{array}$} \\
\hline & & & \\
\hline & Digitizer & $\begin{array}{l}i-80286 \\
i-80287\end{array}$ & \\
\hline
\end{tabular}

Fig. 4. Construction of hardwares in the automatic ECP analysing system.
ECP/SEM で得られた ECP 画像を順次ハードディス クに記録し（最大 240 画像）, 測定の終了した後, 無人 で自動線画化，自動解析処理を実行するものである.

\section{$3 \cdot 3$ ソフトウエアーの構成}

Fig. 5 は自動線画化, 自動解析システムのフロー チャートを示す (OS は MS-DOS を使用).

(a) 自動線画化処理

(1)ハードディスクに記録した ECP 画像 $(512 \times 480$ の画素で 256 の階調を有する) を画像プロセッサーに転 送後シェーディング, フィルター処理等による原画強調 処理

(2)処理画像を探索して画像を形成する白および黒線の

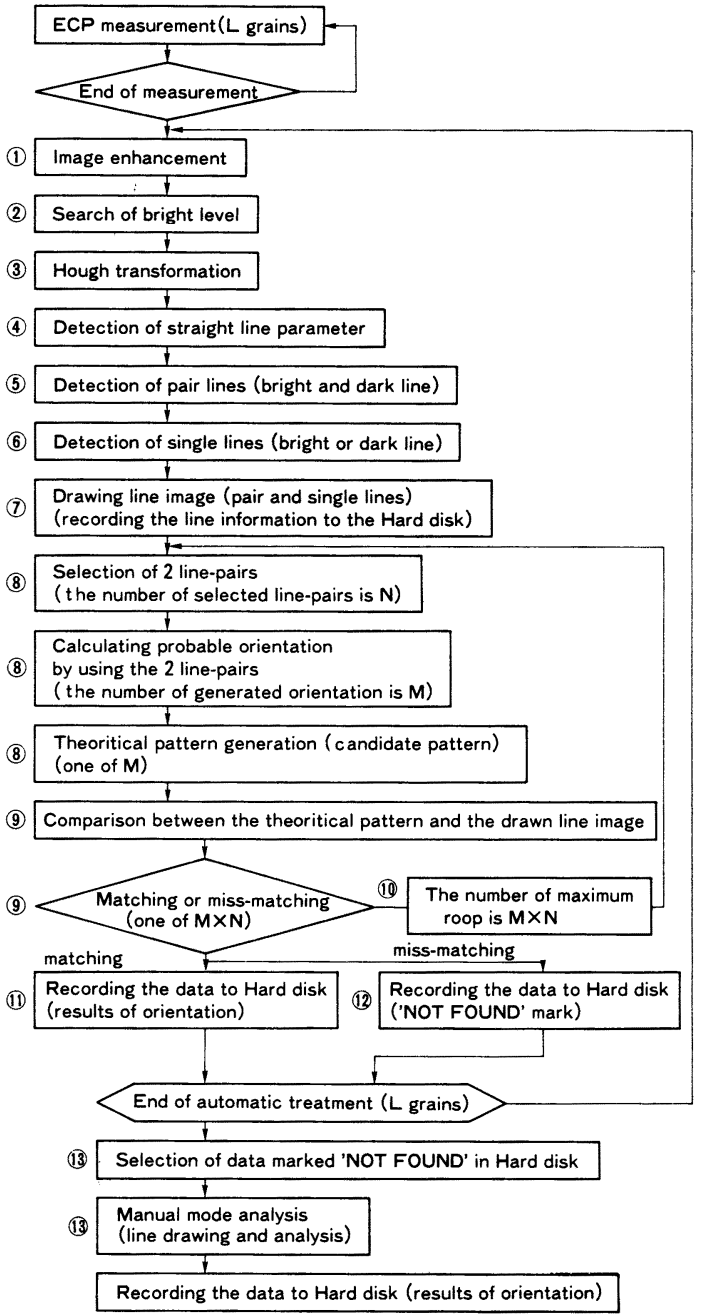

Fig. 5. Sequence of automatic orientation analysis system on ECP. 
輝度レベルの程度を自動算出する輝度レベル探索処理

(3)求められた輝度レベルに従ってそれに相当する輝度 をもつサンプル点をデータから選び出し Hough 変換9) を行う Hough 変換処理

(4)Hough 変換によって作成された $\rho-\theta$ 平面内で, 直 線表現をもつと思われる $\rho, \theta$ を抽出する直線パラメー 夕一抽出処理

(5)上記(3)(4)の処理を白線および黒線に対しておのおの 実行し, 多数の直線パラメーターの中から白線と黒線よ りなる平行なペアー線 (平行線) をすべて抽出する処理

(6)上記(5)で対象外となった直線パラメーターの中でと くに強い直線表現をもつ白あるいは黒よりなるシングル 線の抽出処理

(7)抽出したペアー線，シングル線を線画情報として ディスクに記録する処理

( b ) 自動解析処理

上記の自動線画化処理に引き続いて以下の自動解析処 理を行わせる.

(8)ディスクに記録された線画情報の中から，2組のぺ アー線を選択（できるだけ幅が狭く，両者が画像の中心 付近で交叉し，その交叉角が直角に近いなどの基準で 2 組選択する）し，それをもとに計算された結晶方位から 理論的に予測される数種類の候補パターンをパソコン内 に発生させる.

(9)発生した候補パターンとペアーおよびシングル線よ り構成されている線画像とを順次比較照合し, 両者が もっともよくマッチング (両者のマッチングは最小自乗 法により最適解を選択）したものを解とする解析処理

(10両者がマッチングしない場合は別の 2 組のペアー線 を改めて選択し, それにもとついて発生させた数種類の 候補パターンと線画像との比較照合を順次行う。マッチ ングする候補パターンが得られるまでこの手順を繰り返 す.

(11)マッチングした候補パターンの方位をディスクに記 録する処理

(12)上記処理において選択された候補パターンのいずれ もが線画像とマッチングしない場合は 'NOT FOUND' としてディスクに記録する処理

(13)'NOT FOUND’ の ECP についてはディジタイ ザーを使用したマニュアル処理によって線画化し, 方位 解析する処理

(c) 方位解析結果のデー夕処理

フロッピーディスクに結晶粒の番号と解析結果をテキ ストファイルの形式で記録. これを用いて種々のデータ 処理 (たとえば正極点図表示, 逆極点図表示, 対応方位
計算など）を行う。

\section{4. 自動線画化, 解析処理の実際例}

\section{$4 \cdot 1$ 鲜鋭度の高い ECP の場合}

Photo. 2 は鮮鋭度の高い ECP 画像の事例で原画像 (a), 自動線画像 (b) および計算機により発生させた候 補パターンのうちの 2 種類 (c),（d）を示す.（d）にお いては線画像 (赤線) と候補パターン (青線) のマッチ ングが悪いが，(c) では良くマッチングしており，この 候補 (c) が正しい解であることを示している.

\section{$4 \cdot 2$ 鲜鋭度の低い ECP の場合}

前述のように ECP 画像が鮮明な場合はほとんど問題 なく自動解析を行うことができる，しかし，試料に歪み あるいは表面皮膜が存在することによって鮮鋭度が低い ECP しか得られない場合は, 自動線画化が困難になり, ルーチンの大量処理が不可能になる事態も予想される. それゆえ，ECP の不鮮明さが本システムにおける自動 化処理達成の成否におよほす影響について検討した.

Photo. 3 (a) および (d) はそれぞれ (101) および (001) 近傍の方位をもつ珪素鋼単結晶板試料の ECP を 示す. Photo. $3(\mathrm{~b})$, （e）はこれらの単結晶板試料を [001] 方向に $10 \%$ の冷間圧延を施した試料から得られ た ECPでいずれも鮮鋭度が低下していることがわかる (なお, $13 \%$ の冷間压延試料からは ECP は得られなかっ た).しかし、このように人為的に鮮鋭度を低下させた 試料の場合でも, Photo. 3 (c),（f）に示すように自動 線画化は可能であり，また結晶方位のミラー指数 (自動 計算結果) も無歪みの ECP からえられた結果と良く一 致しており,正しく解析されていることが明らかである. このことから $10 \%$ 程度の歪みによる画像の劣化があっ ても正しい解析がなされるものと考えられる.

\section{$4 \cdot 3$ ルーチン測定における自功化処理達成率}

次に実際の試料を用いて，本システムによるルーチン 測定を行う際の自動化処理達成率の評価を行った. 熱処 理条件を変えることにより, 種々の結晶方位および内部 歪みを有す 5 種類の珪素鋼板試料中の 2236 個の結晶粒 についてルーチンに测定し，自動処理を実施した。

Fig. 6 は方位が自動解析できた結晶粒数の割合 (自動 化処理達成率）を示しており，ECP の鮮鋭度が十分で ない結晶粒が多数含まれているにもかかわらず，いずれ の例においても $94 \%$ 以上の高率で自動解析することが できた。このことは本システムが十分実用性をもつこと を示している.

一方, 歪みの存在あるいは結晶粒が小さいことなどに よって自動解析できずに 'NOT FOUND'と出力された 

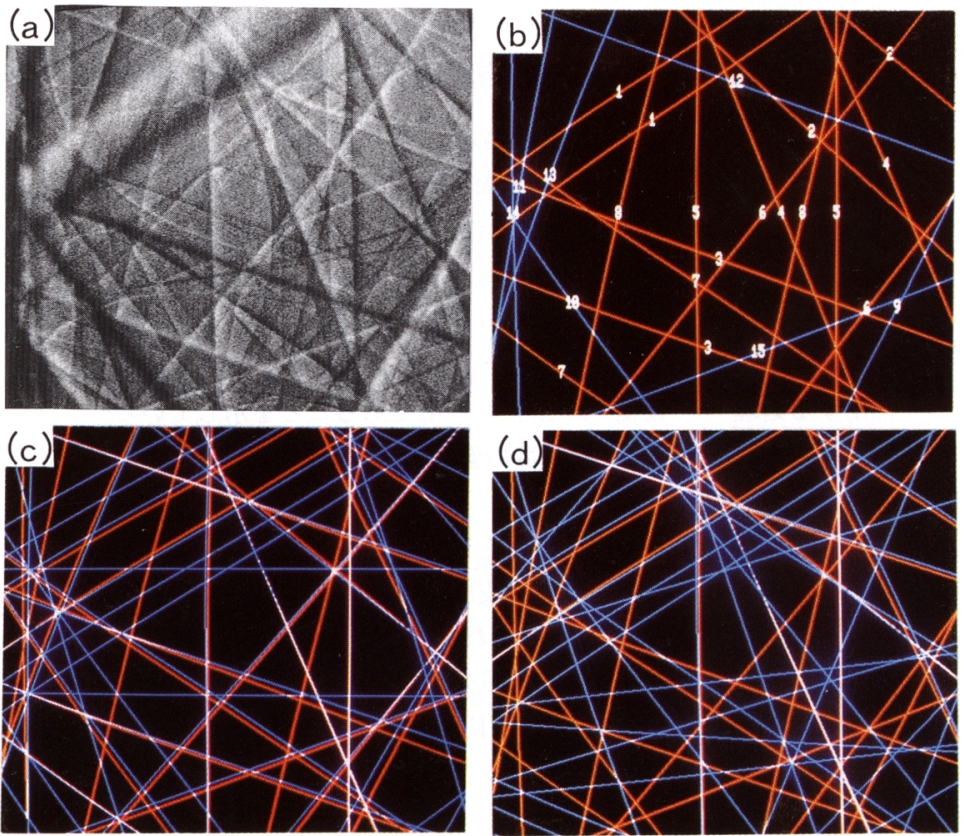

(a) ECP image

(b) Automatically drawn line image

(c) Matching (Candidate pattern 1 for the line image)

(d) Miss-matching (Candidate pattern 2 for the line image

Candidate patterns : Blue lines

Line images: Red lines

Photo. 2. Example of automatic orientation analysis on ECP.
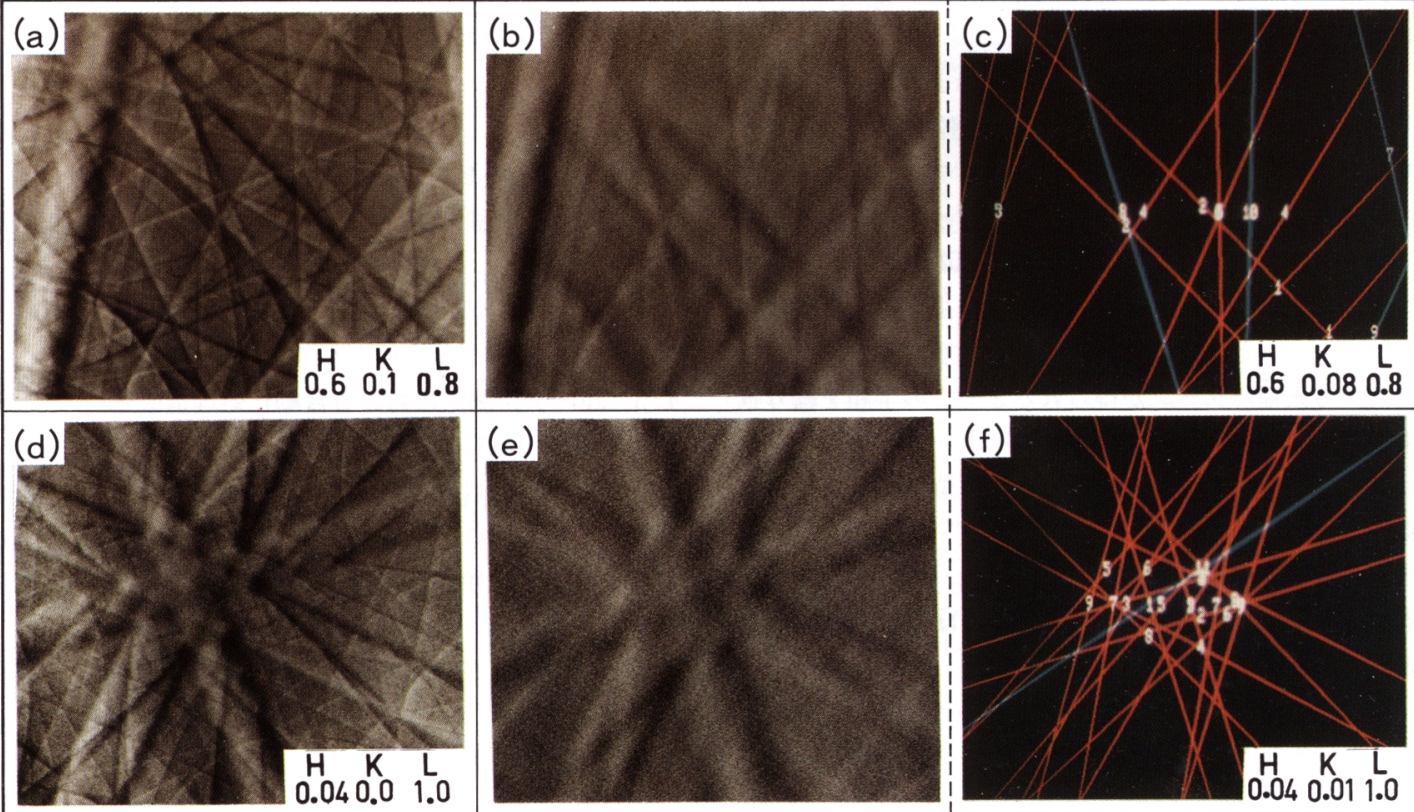

(a ) (d ) ECP images and analysis data of non-deformation steel sheet

(b ) (e ) ECP images of $10 \%$-cold rolled deformation steel sheet

(c ) (f ) Automatically drawn line images and analysis data for ECP images (b, e)

HKL : Fractional representation of the analized indices of the normal directions of the grains

Photo. 3. Example of automatically drawn line image and analysis data of broaden ECP image. 


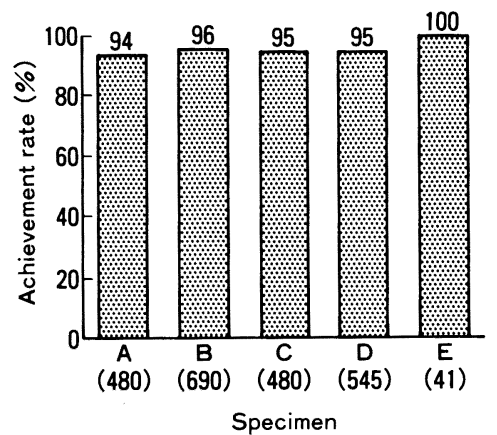

$(n): n$ represents number of measured grains in each specimen

Fig. 6. Achievement rate of automatic orientation analysis.

ECP については，ディジタイザーを使用したマニュア ル処理による線画化によって簡便に方位解析できる.な お，これらマニュアル処理においてはまったく熟練を要 しない.

\section{$4 \cdot 4$ 処理時間}

本システムによる処理時間 (ディスクに記録してある ECP 画像を順次画像プロセッサーに自動転送, 自動線 画化, 自動解析を行い, 結果をディスクに記録するのに 要する時間) は 1 画像あたり約 $4 \mathrm{~min}$ (自動線画化に 3 $\min 15 \mathrm{~s}$, 自動解析に $30 \mathrm{~s}$ で計 $3 \min 45 \mathrm{~s}$ ) である.こ れは.1 日の ECP 測定量を 240 結晶粒とすれば, 夜間 (約 $16 \mathrm{~h}$ ) 無人で自動処理できることを示す．また，自 動解析できなかった ECP についてのマニュアル処理に よる線画化, 解析は約 $1 \mathrm{~min}$ 程度と短い.これらのこと
により従来法に比べ人手と労力が大幅に省力化できた.

\section{$4 \cdot 5$ 自動線画化, 自動解析の正確さ}

自動処理においては解析結果のチェック機能がないた め, 正しい結果が得られているか否かを吟味することが 必要である。そこでランダムな方位をもつ結晶粒 270 個の ECP 画像について本システムによる自動線画化, 自動解析を行った結果と，ディジタイザーを用いてマ ニュアルによる入力, 解析を実施した結果を比較するこ とによって, 本システムによる解析結果の正確さを評価 (板面法線方向 : ND および圧延方向 : RD の両指数も含 めて同時に評価）した. Fig. 7 はその結果の一部を逆極 点図表示 (この場合板面法線方向 : ND のみを表示) し たものであり (111) 近傍の一部 (a', b', c'で示す矢印 の 3 点) を除くとすべて正しく解析されている（本図で は ND のみを表示しているが, 矢印の 3 点以外は $\mathrm{T}_{1}$, $\mathrm{T}_{2}$ の区別を含み $\mathrm{ND}, \mathrm{RD}$ とも正しく解析されている ことは実証済み）ことが明らかである.ここで，正しい 解が得られなかった 3 例の共通点はいずれもその方位が (111) 近傍にのみ存在することである.そこで, (111) 近傍の方位を示すパターン ((111) ポールより約 5 度以 内）について正しい解が得られなかった理由を検討し た。

Photo. 4 は (111) 近傍の ECP 画像の例で, 2 組の 候補パターン (111) 近傍および (111) 近傍を示す。こ のように (111) あるいは (1111) 近傍のパターンは対称 性がよいため両者はきわめて類似しており， $\mathrm{T}_{1}$ および $\mathrm{T}_{2}$ の区別はシングル線 (矢印) の存在位置をもって判 定せざるをえない.この場合は候補である (111) のシ

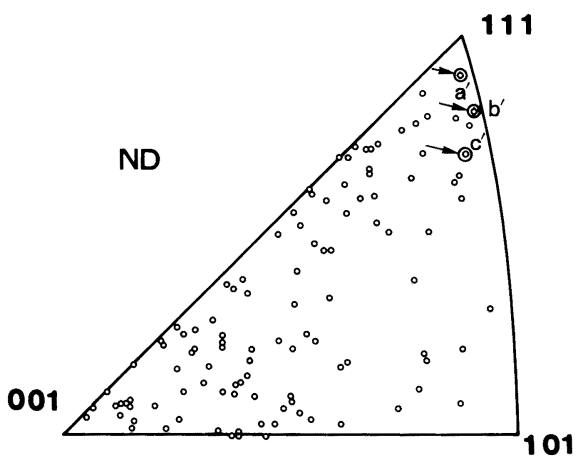

(a)

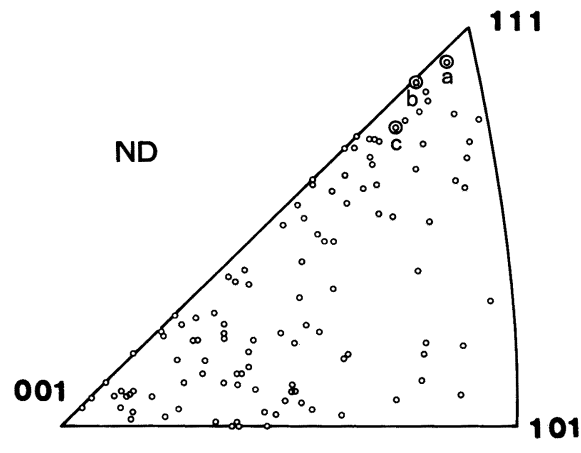

(b)

(a) Automatic line-drawing and automatic analysis (automatic mode)

(b) Manual line-drawing and manual analysis (manual mode)

$a^{\prime}, b^{\prime}, c^{\prime}$ (Arrow mark) : Miss-matched orientation

$a, b, c:$ Matched orientation (manually corrected)

ND : Normal direction of grains

$001,101,111$ : Pole of the stereographic triangle

Fig. 7. Comparison of the results of automatic and manual mode for line-drawing and analysis. 


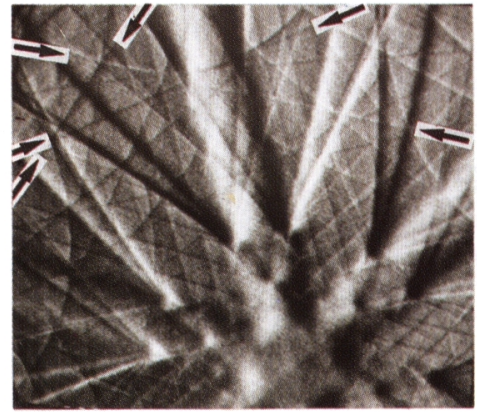

(a)

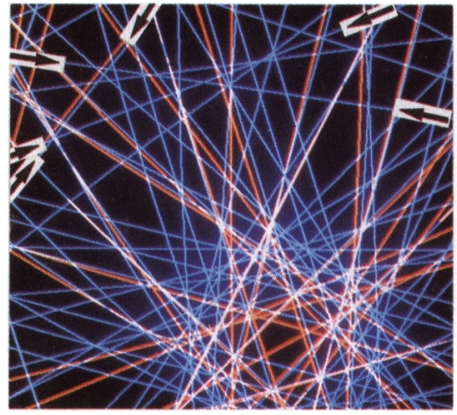

(b)

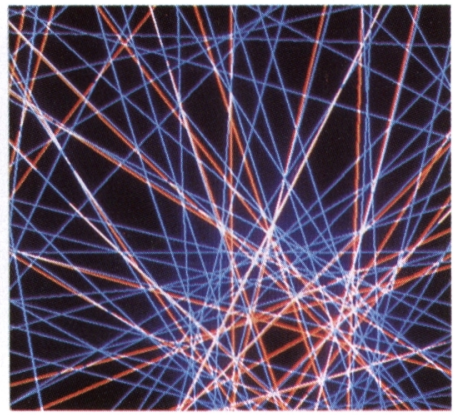

(c) (a) ECP image of nearly (111)

Candidate patterns : Blue lines Line images : Red lines ND : Normal Direction
(b) Matching (Candidate pattern 1 for the line image) $\mathrm{H} \quad \mathrm{K} \quad \mathrm{L}$
ND $\quad 0.54 \quad 0.53 \quad 0.66$ RD $-0.84 \quad 0.25 \quad 0.49$
(c) Miss-matching (Candidate pattern 2 for the line image) $\mathrm{H} \quad \mathrm{K} \quad \mathrm{L}$
ND $\quad 0.61 \quad-0.49 \quad 0.62$
$\begin{array}{llll}\text { RD } & 0.77 & 0.56 & -0.32\end{array}$

Photo. 4. Comparison between matching and miss-matching of nearly (111) ECP images.

ングル線の位置が ECP 画像と合致していることにもと づき $\mathrm{T}_{1}$ と判定できる(なお，解析時においてはマッチ ングの合否を判定するのみ)。この例のように(111) 近 傍あるいは $(1 \overline{1} 1)$ 近傍の ECP については, 自動線画化 処理の際にシングル線の存在を認識することが困難な場 合が多く，マニュアルによる判定が必要となる。それゆ え現状では，(111）あるいは（1111）近傍の方位をもつ結 晶粒の ECP (該当する結晶粒番号のみを出力できる) について正確な方位解析を行うためには, 自動線画化, 自動解析後, その妥当性をマニュアル処理によって確認 することが重要と考えている(処理時間は $30 \mathrm{~s}$ /画像).

\section{5. 結言}

パソコン, 画像プロセッサーの活用および処理ソフト の開発による実用的な ECP の自動線画化, 自動解析シ ステムを開発した。そのポイントは

1. 自動線画化, 自動解析処理の高速化; パソコンレ ベルで 1 画像約 $4 \mathrm{~min}$ 以内と短く, 240 画像を一晚で無 人処理することができる.

2.ルーチンの ECP 測定において約 $95 \%$ 以上の自動 線画化, 自動解析処理を達成.

3. 鮮鋭度不足にもとづく自動解析できなかった ECP についてはマニュアルによる線画化, 解析処理を簡便に 行うことができる (1 min/画像).
4. 自動解析の正確さは (111), (1111) 近傍のみを除い て極めて良い.（111)，（1111）の区別はマニュアル解析 にて簡便に行うことができる $(30 \mathrm{~s} /$ 画像 $)$.

本システムの開発により，熟練者でなくとも ECP に よる結晶方位の解析を簡便, 迅速に行うことが可能とな り, 省力化と高速処理化が達成できた。将来は, さらに $\mathrm{ECP} / \mathrm{SEM}$ に自動試料移動ステージを組み込むことに より，ECPによる完全自動結晶方位解析システムが実 現可能である。

今後, 本システムは個々の結晶粒の方位情報を正確, 迅速に測定解析する要求に対して十分威力を発揮する方 法であり，材料解析の一分野をになう有力な手段として 活用できるものと期待できる.

\section{文献}

1 ) 森 実, 石田洋一, 加藤正夫: 日本金属学会誌, 41 (1977), p. 326

2 ) 桃井 元, 橋本 敏, 三浦 精: 日本材料学会学術講演会 前刷, 35 (1985), p. 305

3 ) Y. Ishida, M. Mori, A. ARimoto and M. OnoE: ICOTOM 6, Tokyo (1981), p. 601

4 ) 清水 亮, 太田国照, 原勢二郎: 鉄と鋼, 70 (1984), S 1322

5 ) 船木秀一, 谷野 満, 釜 三夫, 森実: 鉄と鋼, 70 (1984), S 1321

6 ) 船木秀一, 谷野 満: 製鉄研究 (1986) 323, p. 39

7 ) 山本敏行, 高嶋 進: 日本金属学会会報, 13 (1974), p. 177

8 ) D. G. Coates: Phil. Mag., 16 (1967), p. 1179

9 ) 長尾 真: 画像認識論 (1983), p. 72 [コロナ社] 